\title{
ARTICLE
}

Epidemiology

\section{Predictors of serum cobalamin and its association with homocysteine in community-dwelling older adults}

\author{
Alexandra Jungert $^{1} \cdot$ Monika Neuhäuser-Berthold $^{1}$
}

Received: 10 September 2018 / Revised: 23 October 2018 / Accepted: 6 November 2018 / Published online: 4 December 2018

(c) The Author(s) 2018. This article is published with open access

\begin{abstract}
Background/objectives This study investigates the predictors of serum cobalamin concentrations in community-dwelling older adults and the relationship between serum cobalamin and plasma homocysteine.

Subjects/methods Serum cobalamin and plasma homocysteine were measured by SimulTRAC-SNB radio assay and HPLC, respectively. Linear multiple regression analyses were performed with cross-sectional data of 352 participants aged 60-90 years to examine (1) the predictors of serum cobalamin and (2) the association between cobalamin and homocysteine status. Age, sex, body composition, diet, supplement use, smoking, serum folate, serum pyridoxal 5'-phosphate, serum creatinine, and selected diseases were considered as potential predicting/confounding factors.

Results Median values of serum cobalamin, plasma homocysteine, and dietary cobalamin intake were $256 \mathrm{pmol} / \mathrm{L}, 9.7 \mu \mathrm{mol} /$ $\mathrm{L}$, and $5.7 \mu \mathrm{g} / \mathrm{day}$, respectively. In multiple regression analysis, cobalamin intake, sex, body composition, serum creatinine and smoking did not predict serum cobalamin (all $P>0.05)$. In contrast, age $(\beta=0.111, P=0.031)$, serum folate $(\beta=0.410$, $P<0.001)$ and diagnosis of chronic inflammatory bowel disease (IBD) $(\beta=0.101, P=0.037)$ were positively and cancer diagnosis $(\beta=-0.142, P=0.003)$ was negatively associated with serum cobalamin. The model explained $23 \%$ of the variability of serum cobalamin. After exclusion of subjects with IBD/cancer diagnosis and/or vitamin B/multi-vitamin supplementation, only serum folate remained as positive predictor of serum cobalamin $(\beta=0.407, P<0.001)$. Serum cobalamin was positively associated with inverse-transformed plasma homocysteine before $(\beta=0.298, P<0.001)$ and after $(\beta=0.199, P<0.001)$ multiple adjustments.

Conclusions Serum folate but not cobalamin intake or age proves to be a main predictor of cobalamin status. Nevertheless, independent of serum folate and other potential confounders, serum cobalamin is inversely associated with plasma homocysteine.
\end{abstract}

\section{Introduction}

There is an ongoing debate on whether cobalamin intake should be increased in advanced age compared to younger ages. In light of this, higher reference values for older adults are discussed, as well as the necessity of cobalamin supplements in advanced age. This is based on observations that older individuals more often have an inferior cobalamin status [1-3], which might contribute to an age-related decline in cognitive function and an increased risk of

Monika Neuhäuser-Berthold

monika.neuhaeuser-berthold@ernaehrung.uni-giessen.de

1 Institute of Nutritional Science, Justus Liebig University, Goethestrasse 55, D-35390 Giessen, Germany cardiovascular diseases $[4,5]$. The involvement of cobalamin in homocysteine metabolism might be one underlying mechanism of these associations.

The clinical relevance of a lower cobalamin status found in older subjects is unclear. First, the observed lower levels of cobalamin status parameters in these studies were not accompanied by classical hematological manifestations [6]; second, boundary values used to classify cobalamin deficiency or insufficiency are still under debate [3]; third, results regarding potential associations of either low serum cobalamin or cobalamin intake with cognitive decline [7-9] and cardiovascular diseases [10-13] are inconsistent.

Although pernicious anemia and severe atrophic gastritis are more prevalent in older than in younger subjects and cause clinical cobalamin deficiency [14], this relationship cannot be used to infer a higher cobalamin requirement of the general older population. In view of the current dietary 
reference values, insufficient cobalamin intake is rare in European adults including older subjects [15]. However, little is known on other potential determining factors of cobalamin status in community-dwelling older adults.

Therefore, the present study investigates whether dietary cobalamin intake is associated with serum cobalamin in older subjects independently of age, sex, body composition, supplement use, smoking behavior, serum folate, serum creatinine, and selected diseases. Furthermore, the association of serum cobalamin with plasma homocysteine is investigated by considering folate and vitamin $\mathrm{B}_{6}$ status.

\section{Methods}

\section{Study population and design}

Subjects were participants in a prospective cohort study, in which the nutritional and health status of communitydwelling senior citizens in Giessen, Germany (GISELA study) were investigated between 1994 and 2014 on multiple follow-ups. The study protocol was approved by the Ethical Committee of the Faculty of Medicine, Justus Liebig University, Giessen, Germany. All participants provided written informed consent. Recruitment was accomplished through notices at senior citizens' meetings and medical practices, advertisements in local newspapers and subjects already participating. For enrollment, subjects had to be at least 60 years of age, physically mobile and available around Giessen on a long-term basis. Measurements took place after an overnight fast in the Institute of Nutritional Science in Giessen between July and October. A total of 587 subjects were enrolled but not all of the subjects participated in every follow-up.

The present analysis is based on cross-sectional data from the follow-up year 2002, which provided the largest sample size. From the 403 subjects participating in that year, subjects were excluded because of missing data on serum cobalamin $(n=3)$, body composition $(n=2)$, dietary intake $(n=34)$, general use of supplements/medicine $(n=18)$ and smoking behavior $(n=15)$. Two subjects declared non-fasting conditions and thus were not included in the analysis. The final study cohort consisted of 246 women and 106 men.

\section{Anthropometric data and body composition}

Weight and height were assessed in light clothing without shoes via a calibrated scale with an integrated stadiometer, and body mass index (BMI) was calculated. A singlefrequency $(50 \mathrm{kHz})$ bioelectrical impedance analyzer (Akern-RJL BIA 101/S ; Data Input, Frankfurt, Germany) and the formula of Roubenoff et al. [16] were used to determine fat-free mass (FFM) and fat mass (FM).

\section{Dietary assessment and parameters related to lifestyle and health}

Dietary intakes were determined using a 3-day estimated dietary record consisting of 146 food items and beverages, which was developed and validated for the GISELA study [17]. The nutrient and energy content of the food items was calculated by means of the German Food Code and Nutrition Data Base version 3.02 [18]. Nutrient intake was computed as individual mean values of the 3 days recorded. The use of B-vitamins and multi-vitamin supplements was assessed by means of two self-administered questionnaires and data of both questionnaires were combined to form the variable "vitamin B/multi-vitamin supplementation (no vs. yes)". One of these questionnaires scrutinized the use of vitamin supplements during 3 days before blood sampling by brand name, frequency and dosage [19]. The other questionnaire assessed the overall use of vitamin $\mathrm{B} / \mathrm{multi-}$ vitamin supplements. Total cobalamin intake represents the sum of dietary and supplementary cobalamin intake assessed by the above mentioned 3-day records divided by three to calculate daily intake.

Data on smoking behavior and medication were obtained by self-administered questionnaires. Smoking behavior was classified as a dichotomous variable in never-smokers vs. current/ex-smokers. Participants reported their diseases diagnosed by their physician using a questionnaire including predefined disease categories.

\section{Measurements in blood}

After an overnight fast, venous blood was drawn into serum tubes, EDTA-containing tubes, and heparin-containing tubes. Plasma and serum aliquots were stored at $-70^{\circ} \mathrm{C}$ until analyzed. Serum cobalamin and folate were measured by SimulTRAC-SNB Radioassay Kit (MP Biomedicals, Eschwege, Germany). Plasma homocysteine was assessed by high performance liquid chromatography (HPLC) with fluorimetric detection using a modified method of Ubbink et al. [20]. Serum pyridoxal 5'-phosphate (PLP) was measured as indicator of vitamin $\mathrm{B}_{6}$ status by HPLC with fluorimetric detection using a modified method of Zempleni et al. [21]. Serum creatinine was analyzed using the Jaffé reaction [22]. Between-days CVs were $13.4 \%$ for cobalamin, $5.4 \%$ for folate, $1.5 \%$ for PLP, $3.3 \%$ for homocysteine and $3.2 \%$ for creatinine.

\section{Statistical analyses}

Because some variables deviated from normal distribution (tested by Kolmogorov-Smirnov test), data were expressed as median and interquartile range if not stated otherwise. As serum cobalamin, folate and PLP, as well as dietary intake 
Table 1 Descriptive characteristics of the study population in 2002

\begin{tabular}{|c|c|c|c|c|c|c|c|c|c|c|}
\hline & \multicolumn{3}{|c|}{ Entire cohort $(n=352)$} & \multicolumn{3}{|c|}{ Women $(n=246)$} & \multicolumn{3}{|c|}{$\operatorname{Men}(n=106)$} & \multirow[b]{3}{*}{$P^{\mathrm{a}}$} \\
\hline & \multirow[t]{2}{*}{ Median } & \multicolumn{2}{|c|}{ Percentiles } & \multirow[t]{2}{*}{ Median } & \multicolumn{2}{|c|}{ Percentiles } & \multirow[t]{2}{*}{ Median } & \multicolumn{2}{|c|}{ Percentiles } & \\
\hline & & 25 & 75 & & 25 & 75 & & 25 & 75 & \\
\hline Age (years) & 72.00 & 68.00 & 75.00 & 72.00 & 67.00 & 76.00 & 72.00 & 68.00 & 75.00 & 0.908 \\
\hline BMI $\left(\mathrm{kg} / \mathrm{m}^{2}\right)$ & 26.79 & 24.40 & 29.66 & 26.85 & 24.34 & 29.93 & 26.58 & 24.63 & 29.38 & 0.713 \\
\hline $\mathrm{FM}(\%)$ & 40.19 & 33.36 & 44.68 & 42.80 & 38.65 & 46.33 & 30.38 & 27.40 & 34.38 & $<0.001$ \\
\hline FFM (kg) & 41.65 & 38.32 & 51.69 & 39.43 & 37.42 & 42.02 & 54.67 & 51.90 & 58.13 & $<0.001$ \\
\hline Serum cobalamin (pmol/L) & 255.53 & 176.15 & 364.11 & 263.44 & 184.27 & 383.35 & 239.38 & 168.39 & 310.20 & 0.039 \\
\hline Dietary cobalamin intake ( $\mu \mathrm{g} /$ day) & 5.73 & 4.32 & 7.91 & 5.59 & 4.25 & 7.46 & 5.98 & 4.72 & 8.58 & 0.011 \\
\hline Total cobalamin intake $(\mu \mathrm{g} / \mathrm{day})^{\mathrm{b}}$ & 6.06 & 4.66 & 8.31 & 5.99 & 4.49 & 7.88 & 6.72 & 4.87 & 9.80 & 0.025 \\
\hline Serum folate (nmol/L) & 18.39 & 12.19 & 26.63 & 18.83 & 12.21 & 27.75 & 16.68 & 11.15 & 24.12 & 0.101 \\
\hline Dietary total folate intake $(\mu \mathrm{g} / \mathrm{day})$ & 242.18 & 198.93 & 300.16 & 240.30 & 197.17 & 298.57 & 245.21 & 199.67 & 302.31 & 0.490 \\
\hline Serum PLP (nmol/L) & 39.00 & 25.00 & 58.00 & 38.50 & 25.00 & 58.00 & 39.00 & 26.00 & 59.00 & 0.568 \\
\hline Dietary vitamin $B_{6}$ intake (mg/day) & 1.52 & 1.19 & 1.86 & 1.48 & 1.17 & 1.82 & 1.58 & 1.25 & 2.07 & 0.062 \\
\hline Plasma homocysteine $(\mu \mathrm{mol} / \mathrm{L})$ & 9.69 & 8.16 & 11.86 & 9.36 & 8.04 & 11.61 & 10.05 & 8.74 & 12.22 & 0.022 \\
\hline \multirow[t]{2}{*}{ Serum creatinine $(\mathrm{mg} / 100 \mathrm{~mL})^{\mathrm{c}}$} & 0.96 & 0.89 & 1.06 & 0.93 & 0.85 & 1.01 & 1.05 & 0.96 & 1.16 & $<0.001$ \\
\hline & & $n$ & $\%$ & & $n$ & $\%$ & & $n$ & $\%$ & \\
\hline Current/past smokers & & 136 & 38.6 & & 63 & 25.6 & & 73 & 68.9 & $<0.001$ \\
\hline Vitamin $\mathrm{B} /$ multi-vitamin supplement & sers & 111 & 31.5 & & 82 & 33.3 & & 29 & 27.4 & 0.268 \\
\hline
\end{tabular}

Note: Data are presented as median, 25th and 75th percentiles for continuous variables and absolute and relative frequencies for categorical variables

${ }^{a}$ Mann-Whitney $U$ test and chi-square test for analyzing sex differences

${ }^{\mathrm{b}}$ Twenty-two subjects had missing data on quantitative cobalamin intake by supplements within three days before blood sampling. Therefore, total cobalamin intake could not be calculated for these subjects

${ }^{\mathrm{c} E l e v e n ~ s u b j e c t s ~ h a d ~ m i s s i n g ~ c r e a t i n i n e ~ m e a s u r e m e n t s ~}$

of nutrients were highly skewed, data underwent $\lg _{10}$ transformation. Plasma homocysteine underwent a reciprocal (inverse) transformation to approximate normally distributed residuals.

Descriptive characteristics of the participants were compared between two groups by Mann-Whitney $U$ test when analyzing continuous variables and by chi-square test when analyzing categorical variables. Spearman correlation was used to investigate unadjusted associations of serum cobalamin and cobalamin intake with relevant factors. With the exception of dietary cobalamin intake, only those factors showing a trend for an association with serum cobalamin $(P$ $<0.100$ ) were considered in the subsequent linear multiple regression analysis with enter procedure to examine the predictors of $\lg _{10}$ serum cobalamin.

Linear multiple regression analysis using enter procedure with inverse transformed homocysteine as dependent variable and serum cobalamin as independent variable was performed with adjustments for age, sex, \%FM, smoking behavior, $\lg _{10}$ serum folate, $\lg _{10}$ serum PLP, vitamin $\mathrm{B} /$ multi-vitamin supplementation, $\lg _{10}$ dietary intakes of cobalamin, folate and vitamin $\mathrm{B}_{6}$, as well as serum creatinine, lifetime diagnosis of cancer and chronic inflammatory bowel diseases (IBD). Analyses were performed using the statistical software package (SPSS 24.0, IBM, New York, USA). Significance level was set at $P<$ 0.05 (two-sided).

\section{Results}

Characteristics of the subjects are presented in Table 1. Women showed higher serum cobalamin and lower plasma homocysteine despite lower dietary cobalamin intake than men.

Serum cobalamin, plasma homocysteine and dietary cobalamin intake ranged between 12.8 and $4767 \mathrm{pmol} / \mathrm{L}$, 3.8 and $30.9 \mu \mathrm{mol} / \mathrm{L}$, and 1.2 and $28.2 \mu \mathrm{g} /$ day, respectively. Serum cobalamin $\leq 148 \mathrm{pmol} / \mathrm{L}$ was present in $17 \%$ of the subjects, and $20 \%$ showed a dietary cobalamin intake $<4.0$ $\mu \mathrm{g} /$ day, with no sex differences in this respect $(P>0.05)$. Subjects with serum cobalamin $\leq 148 \mathrm{pmol} / \mathrm{L}$ vs. $>148$ pmol/L showed equal dietary cobalamin intakes [5.9 (4.47.9) vs. 5.7 (4.3-7.9) $\mu \mathrm{g} /$ day, $P=0.777$ ]. Likewise, serum 


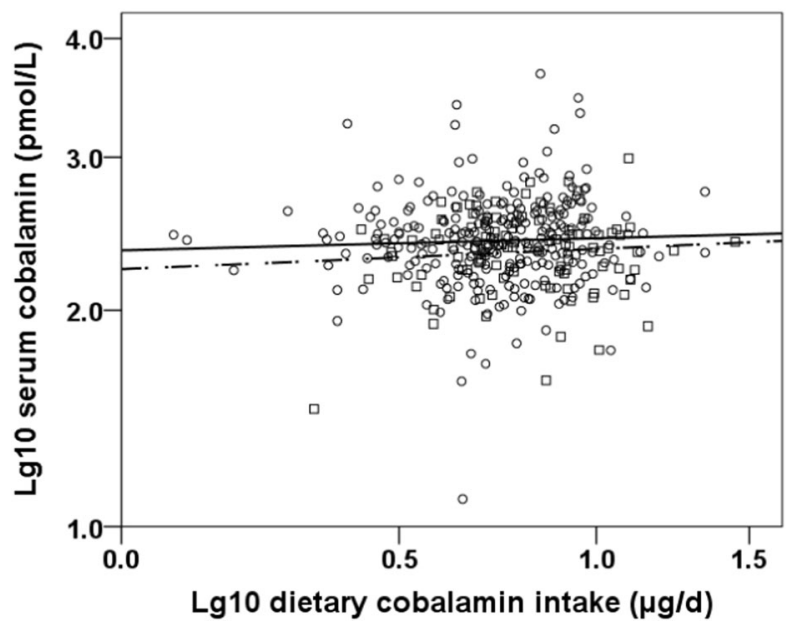

Fig. 1 Association between $\lg _{10}$ dietary cobalamin intake and $\lg _{10}$ serum cobalamin stratified by sex (solid line and $(O)$ open circle represent women; broken line and $(\square)$ open square represent men)

cobalamin did not differ between subjects with dietary intake levels $<$ and $\geq 4.0 \mu \mathrm{g} /$ day [264 (180-332) vs. 253 (174-370) $\mathrm{pmol} / \mathrm{L}, P=0.702$ ]. Vitamin $\mathrm{B} /$ multi-vitamin supplement users had higher serum cobalamin than nonusers [308 (219-433) vs. $237(160-339)$ pmol/L, $P<$ 0.001]. The unadjusted association between $\lg _{10}$ dietary cobalamin intake and $\lg _{10}$ serum cobalamin stratified by sex is illustrated in Fig. 1.

Subjects diagnosed with stomach disease $(n=67)$, liver/ gall bladder disease $(n=64)$ or urinary tract/kidney disease $(n=15)$ until 2002 did not differ in serum cobalamin from subjects without such a disease (all $P>0.05$ ). Subjects with cancer diagnosis $(n=44)$ had lower serum cobalamin than those not reporting cancer diagnosis [204 (128-298) vs. 259 (186-373) $\mathrm{pmol} / \mathrm{L}, P=0.003]$, but had equal dietary cobalamin intakes [6.1 (4.5-9.7) vs. 5.7 (4.3-7.7) $\mu \mathrm{g} /$ day, $P$ $=0.119]$. Subjects with IBD $(n=10)$ had higher serum cobalamin [320 (273-574) vs. 252 (174-363) pmol/L, $P=$ $0.040]$ and higher dietary cobalamin intake [8.0 (5.9-11.4) vs. 5.7 (4.3-7.9) $\mu \mathrm{g} / \mathrm{day}, P=0.022]$ than subjects without IBD. Subjects who reported to use stomach medicine $(n=$ 41) did not differ in serum cobalamin [251 (188-355) vs. 256 (174-369) $\mathrm{pmol} / \mathrm{L}, P=0.849]$ or dietary cobalamin intake [5.8 (4.3-7.1) vs. $5.7(4.3-7.9) \mu \mathrm{g} / \mathrm{day}, P=0.797$ ] from subjects who reported not to use these medications.

The results of the Spearman correlation are given in Table 2. Serum cobalamin correlated with total cobalamin intake, sex, smoking, vitamin B/multi-vitamin supplementation, diagnosis of cancer and IBD, consumption of milk/milk products and serum folate. Dietary intake of cobalamin correlated with sex, age, FFM, diagnosis of IBD and consumption of milk/milk products, meat/meat products, eggs, fish and alcoholic beverages. Current/past smokers showed lower serum cobalamin compared with never smokers [239 (173-316) vs. 263 (184-397) pmol/L, $P=0.018]$, whereas cobalamin intakes were almost identical [5.7 (4.3-7.9) vs. $5.7(4.3-7.9) \mu \mathrm{g} /$ day, $P=0.617]$. In sex-specific analysis, no differences in serum cobalamin according to smoking behavior were evident $(P>0.05)$.

The results of the linear multiple regression analyses are presented in Table 3. Age, $\lg _{10}$ serum folate, as well as diagnosis of cancer and IBD were significant predictors of $\lg _{10}$ serum cobalamin. The regression model explained $23 \%$ of the variance in $\lg _{10}$ serum cobalamin. After nine subjects with extreme cobalamin concentrations $(12.8$ and $\geq 1000$ $\mathrm{pmol} / \mathrm{L}$ ) were excluded to approximate normal distribution of residuals, similar results were found, except for the age effect, which became non-significant, and an increase in the explained variance to $28 \%$ (data not shown). The results remained unchanged when $\lg _{10}$ dietary cobalamin intake ( $\mu \mathrm{g} / \mathrm{day})$ was replaced by consumption of milk/milk products (g/day) or by $\lg _{10}$ cobalamin intake via milk/milk products ( $\mu \mathrm{g} /$ day) (data not shown). Furthermore, when $\lg _{10}$ dietary cobalamin intake was replaced by $\lg _{10}$ total cobalamin intake, the results were equal (Table 3). When subjects diagnosed with IBD or cancer and/or use of vitamin B/ multi-vitamin supplements were excluded, only $\lg _{10}$ serum folate was significantly associated with $\lg _{10}$ serum cobalamin (Table 3).

In linear regression analyses, $\lg _{10}$ serum cobalamin was positively associated with inverse-transformed plasma homocysteine before $(B<0.001, \beta=0.298, P<0.001)$ and after $(B<0.001, \beta=0.199, P<0.001)$ adjustments for age, sex, $\% \mathrm{FM}$, smoking behavior, $\lg _{10}$ serum folate, $\lg _{10}$ serum PLP and use of vitamin B/multi-vitamin supplements. The results remained unchanged when $\lg _{10}$ intakes of cobalamin, folate and vitamin $\mathrm{B}_{6}$, as well as serum creatinine and diagnosis of cancer and IBD were considered as additional covariables $(B=0.024, \beta=0.233, P<0.001)$. In this analysis, the sample size was reduced to 341 subjects because of missing values for serum creatinine. After excluding subjects with serum cobalamin $\geq 1000 \mathrm{pmol} / \mathrm{L}(n=8), \lg _{10}$ serum cobalamin was still associated with inversetransformed plasma homocysteine before $(B=0.031, \beta=$ $0.269, P<0.001)$ and after $(B=0.014, \beta=0.122, P=$ 0.026 ) adjustments for age, sex, \%FM, smoking behavior, $\lg _{10}$ serum folate, $\lg _{10}$ serum PLP and use of vitamin $\mathrm{B} /$ multi-vitamin supplements.

\section{Discussion}

The main findings of the present study are that (1) neither dietary cobalamin intake nor the use of supplements are predictors of serum cobalamin after considering other covariables, whereas serum folate and diseases, such as IBD and cancer, are main predictors and (2) serum cobalamin is 
Table 2 Spearman correlations to find variables associated with serum cobalamin and dietary cobalamin intake $(n=352)$

\begin{tabular}{|c|c|c|c|c|}
\hline & \multicolumn{2}{|c|}{$\begin{array}{l}\text { Serum cobalamin } \\
(\mathrm{pmol} / \mathrm{L})\end{array}$} & \multicolumn{2}{|c|}{$\begin{array}{l}\text { Dietary intake of } \\
\text { cobalamin }(\mu \mathrm{g} / \mathrm{day})\end{array}$} \\
\hline & $r_{R h o}$ & $P$ & $r_{R h o}$ & $P$ \\
\hline Dietary cobalamin intake ( $\mu \mathrm{g} /$ day) & 0.019 & 0.728 & & \\
\hline Total cobalamin intake $(\mu \mathrm{g} / \mathrm{day})^{\mathrm{a}}$ & 0.112 & 0.042 & 0.896 & $<0.001$ \\
\hline Sex (female vs. male) & -0.110 & 0.039 & 0.135 & 0.011 \\
\hline Age (years) & 0.074 & 0.166 & 0.190 & $<0.001$ \\
\hline FFM (kg) & -0.094 & 0.079 & 0.134 & 0.012 \\
\hline Current/past smoking (no vs. yes) & -0.126 & 0.018 & 0.027 & 0.618 \\
\hline Vitamin B/multi-vitamin supplements (no vs. yes) & 0.231 & $<0.001$ & -0.081 & 0.130 \\
\hline Consumption of milk/milk products (g/day) & 0.160 & 0.003 & 0.304 & $<0.001$ \\
\hline Consumption of meat/meat products (g/day) & 0.050 & 0.350 & 0.468 & $<0.001$ \\
\hline Consumption of eggs (g/day) & -0.023 & 0.674 & 0.125 & 0.019 \\
\hline Consumption of fish (g/day) & 0.054 & 0.309 & 0.541 & $<0.001$ \\
\hline Consumption of alcohol free beverages (g/day) & 0.067 & 0.211 & 0.056 & 0.298 \\
\hline Consumption of alcoholic beverages (g/day) & -0.025 & 0.639 & 0.108 & 0.042 \\
\hline Serum creatinine $(\mathrm{mg} / 100 \mathrm{~mL})^{\mathrm{b}}$ & -0.016 & 0.769 & 0.036 & 0.511 \\
\hline Serum folate $(\mathrm{nmol} / \mathrm{L})$ & 0.470 & $<0.001$ & -0.071 & 0.182 \\
\hline
\end{tabular}

associated with plasma homocysteine independent of folate and vitamin $\mathrm{B}_{6}$ status in community-dwelling older adults.

At present, there is no generally accepted cut-off value with regard to adequate serum cobalamin concentrations. For the diagnosis of cobalamin deficiency, the cut-off of $148 \mathrm{pmol} / \mathrm{L}$ has shown a good sensitivity [15, 23] and therefore was applied in our study. Although serum holotranscobalamin is regarded as the most specific biomarker to characterize adequate cobalamin status, uniform cut-off values are missing [15]. However, concentrations of holotranscobalamin and cobalamin showed a comparable performance as regards screening of subjects for cobalamin deficiency [24].

In the present study, a significant number of subjects had low serum cobalamin $(<148 \mathrm{pmol} / \mathrm{L})$, which could not be explained by low intakes. A similar finding was reported in younger women [25]. Despite the wide range of dietary cobalamin intake in our study ( 1.2 to $28.2 \mu \mathrm{g} / \mathrm{day}$ ), no association with serum cobalamin was found. Other studies reported dietary cobalamin intake to be significantly associated with serum cobalamin [25-27], however, due to the differences in study design and populations, the comparison of the studies is limited. The absorption of cobalamin differs by food source and ingested amount of cobalamin with foods rich in cobalamin, such as liver, showing lower absorption rates of cobalamin than foods containing lower amounts of cobalamin, such as milk, fish and eggs [28, 29]. In the Hordaland Homocysteine Study, cobalamin intake from dairy products led to the greatest increase in plasma cobalamin in comparison to cobalamin intake from other food sources [30]. Although the overall consumption of milk/milk products correlated with cobalamin intake and serum cobalamin before adjustments in our study, cobalamin intake via milk/milk products was not associated with serum cobalamin after considering relevant covariables.

Likewise, the use of vitamin B/multi-vitamin supplements did not predict serum cobalamin after adjustments for other covariables. The same was true when the use of cobalamin supplements within 3 days before examination was analyzed as potentially predicting variable (data not shown). As described earlier, the amounts of cobalamin taken via supplements were rather modest in the GISELA study [19]. Normally, a cobalamin intake of $1.5-2 \mu \mathrm{g}$ per meal results in saturation of the intestinal absorption via intrinsic factor [31]. Furthermore, the associations between cobalamin intake and status parameters seem to reach a plateau at daily cobalamin intakes around 4-7 $\mu \mathrm{g}[26,27,32]$. Thus, the lacking association of cobalamin intake by diet and supplements with serum cobalamin in our cohort may be due to the fact, that the overall cobalamin intake was sufficient.

In the present study, serum folate was the main predictor of serum cobalamin. Significant correlations of serum/ plasma folate with serum/plasma cobalamin were reported in other studies [33-36]. While the metabolic interaction of folate and cobalamin with regard to the transfer of methyl groups is well understood and cobalamin deficiency can lead to an increase in serum folate [37], less is known about possible mechanisms that could explain the pronounced 
Table 3 Multiple regression analyses to identify predictors of $\lg _{10}$ serum cobalamin

\begin{tabular}{|c|c|c|c|c|c|c|c|c|c|}
\hline & \multicolumn{3}{|c|}{ Entire cohort $(n=352)^{\mathrm{a}}$} & \multicolumn{3}{|c|}{$\begin{array}{l}\text { Subjects with detailed } \\
\text { information on cobalamin } \\
\text { intake by supplements }(n \\
=330)^{\mathrm{b}}\end{array}$} & \multicolumn{3}{|c|}{$\begin{array}{l}\text { Subjects without vitamin } \\
\text { B/multi-vitamin } \\
\text { supplements, cancer or } \\
\text { IBD diagnosis }(n=205)^{\mathrm{c}}\end{array}$} \\
\hline & \multicolumn{3}{|c|}{$\begin{array}{l}\mathrm{Lg}_{10} \text { serum cobalamin } \\
(\mathrm{pmol} / \mathrm{L})\end{array}$} & \multicolumn{3}{|c|}{$\begin{array}{l}\mathrm{Lg}_{10} \text { serum cobalamin } \\
(\mathrm{pmol} / \mathrm{L})\end{array}$} & \multicolumn{3}{|c|}{$\begin{array}{l}\mathrm{Lg}_{10} \text { serum cobalamin } \\
(\mathrm{pmol} / \mathrm{L})\end{array}$} \\
\hline & $B$ & $\beta$ & $P$ & $B$ & $\beta$ & $P$ & $B$ & $\beta$ & $P$ \\
\hline Intercept & 1.297 & & $<0.001$ & 1.246 & & $<0.001$ & 1.519 & & $<0.001$ \\
\hline Age (years) & 0.005 & 0.111 & 0.031 & 0.006 & 0.119 & 0.023 & 0.003 & 0.065 & 0.352 \\
\hline Sex (female vs. male) & -0.083 & -0.133 & 0.160 & -0.082 & -0.133 & 0.180 & -0.058 & -0.100 & 0.447 \\
\hline FFM (kg) & 0.003 & 0.099 & 0.302 & 0.004 & 0.106 & 0.287 & 0.002 & 0.051 & 0.700 \\
\hline $\mathrm{Lg}_{10}$ serum folate $(\mathrm{nmol} / \mathrm{L})$ & 0.439 & 0.410 & $<0.001$ & 0.442 & 0.410 & $<0.001$ & 0.457 & 0.407 & $<0.001$ \\
\hline Current/past smoking (no vs. yes) & -0.032 & -0.055 & 0.292 & -0.034 & -0.058 & 0.287 & -0.018 & -0.033 & 0.646 \\
\hline $\operatorname{Lg}_{10}$ dietary cobalamin ( $\mu \mathrm{g} /$ day $)$ & 0.077 & 0.053 & 0.278 & & & & 0.058 & 0.042 & 0.534 \\
\hline $\mathrm{Lg}_{10}$ total cobalamin intake ( $\mu \mathrm{g} /$ day) & & & & 0.081 & 0.065 & 0.199 & & & \\
\hline Use of vitamin $B /$ multi-vitamin supplements (no vs. yes) & 0.031 & 0.050 & 0.336 & 0.017 & 0.027 & 0.624 & & & \\
\hline Lifetime diagnosis of cancer (no vs. yes) & -0.123 & -0.142 & 0.003 & -0.136 & -0.154 & 0.002 & & & \\
\hline Lifetime diagnosis of IBD (no vs. yes) & 0.173 & 0.101 & 0.037 & 0.177 & 0.105 & 0.034 & & & \\
\hline corr. $\mathrm{R}^{2}$ & & 0.231 & & & 0.232 & & & 0.154 & \\
\hline
\end{tabular}

${ }^{a}$ Linear multiple regression analysis with $\lg _{10}$ serum cobalamin concentrations as dependent variable and sex (female vs. male), age (years), FFM $(\mathrm{kg}), \lg _{10}$ dietary intake of cobalamin ( $\mu \mathrm{g} /$ day), use of vitamin $\mathrm{B} /$ multi-vitamin supplements (no vs. yes), smoking behavior (never vs. current/past smoking), cancer diagnosis (no vs. yes), IBD diagnosis (no vs. yes) and $\lg _{10}$ serum folate (nmol/L) as independent variables. Data are shown as non-standardized coefficient beta $(B)$, standardized coefficient beta $(\beta)$ and adjusted coefficient of determination $\left(\right.$ corr. $\left.\mathrm{R}^{2}\right)$

${ }^{\mathrm{b}}$ Linear multiple regression analysis with $\lg _{10}$ serum cobalamin concentrations as dependent variable and sex (female vs. male), age (years), FFM $(\mathrm{kg}), \lg _{10}$ total cobalamin intake ( $\mu \mathrm{g} /$ day), use of vitamin $\mathrm{B} /$ multi-vitamin supplements (no vs. yes), smoking behavior (never vs. current/past smoking), cancer diagnosis (no vs. yes), IBD diagnosis (no vs. yes) and $\lg _{10}$ serum folate (nmol/L) as independent variables. Because 22 participants had missing data on quantitative cobalamin intake by supplements, the sample size was reduced to 330 subjects in this analysis

${ }^{c}$ Linear multiple regression analysis with $\lg _{10}$ serum cobalamin concentrations as dependent variable and sex (female vs. male), age (years), $\lg _{10}$ dietary intake of cobalamin ( $\mu \mathrm{g} /$ day), FFM ( $\mathrm{kg}$ ), smoking behavior (never vs. current/past smoking) and $\lg _{10}$ serum folate (nmol/L) as independent variables

positive association between both vitamins and therefore this deserves further investigation.

In our cohort, besides serum folate, only IBD and cancer proved as robust predictors of serum cobalamin. Cobalamin and folic acid deficiencies are common in patients with IBD for which reason cobalamin preparations may be advised or given parenterally [38], what may explain the positive association of IBD and serum cobalamin in our study. In contrast, we found a negative association of cancer and serum cobalamin. A low cobalamin status has been reported in patients with cancer of the gastrointestinal tract [39] and multiple myeloma [40]. Whether dietary factors, malabsorption and/or metabolic alterations are involved in this relationship requires further exploration.

In the present study, sex, body composition and lifestyle factors were no predictors of serum cobalamin and the initially observed positive effect of age vanished in subanalyses. Thus, we cannot confirm an independent negative effect of age on serum cobalamin in community-dwelling older adults.
Despite higher cobalamin intakes, male subjects had lower serum cobalamin before adjustments. This was also reported in an elderly population in the Netherlands [26]. One explanation could be differences in distribution volume, which may be higher in males due to higher body mass and FFM compared to females. However, we found no association between FFM and cobalamin status and also no association between serum creatinine and serum cobalamin. Serum creatinine was predominantly within reference range and then may rather reflect muscle mass than kidney function [41].

Inverse correlations between current/past smoking and serum cobalamin were reported in some studies [35, 42], while others found no such relation [43] or even higher serum cobalamin in smokers [44]. Before adjustments, we observed lower serum cobalamin in current/past smokers in the entire cohort. This was not the case in sex-specific analysis what may be explained by the fact that male subjects, who represented the vast majority of smokers, had lower serum cobalamin. 
Serum cobalamin was a negative predictor of plasma homocysteine before and after multiple adjustments including serum folate and PLP. We are not aware of any other observational study showing an independent effect of serum cobalamin on homocysteine in community-dwelling older subjects having mostly cobalamin intakes and serum concentrations within reference ranges. A meta-analysis of studies on effects of folic acid supplementation with or without cobalamin on homocysteine levels showed that the addition of cobalamin resulted in additional reductions of homocysteine beyond those due to folic acid [45]. In another study, folic acid supplementation with increasing doses was associated with a decrease in the homocysteine lowering effect, while cobalamin then became a core determinant of plasma homocysteine [46]. Although both folate and cobalamin are required for the remethylation of homocysteine to methionine, the mechanism by which the dependency of the homocysteine lowering effect on cobalamin increases at higher folate intakes is not known. Possible, genetic factors may play a role such as methylentetrahydrofolate reductase and cobalamin dependent polymorphisms [47].

Some limitations must be considered when interpreting the results of this study. Due to the cross-sectional design reverse causality cannot be excluded. We rely on one biomarker to assess cobalamin status and could not include genetic profiles in our assessment. Because of the low prevalence of IBD and cancer, these results should be interpreted with caution. As strengths of our study, we want to point out that the participants were community-dwelling subjects mainly without cobalamin deficiency and that folate, vitamin $\mathrm{B}_{6}$, serum creatinine and body composition were considered as relevant covariables.

In conclusion, our results emphasize that in communitydwelling older adults neither cobalamin intake nor age per se are significant predictors of serum cobalamin, whereas diseases, such as IBD or cancer, may affect cobalamin status. The underlying mechanisms of the strong positive association between serum folate and cobalamin, as well as the robust independent negative association between serum cobalamin and homocysteine warrant further research.

Acknowledgements This research was financed by the core budget of the Department of Human Nutrition, Justus Liebig University Giessen, Germany and did not receive any specific grant from funding agencies in the public, commercial, or not-for-profit sectors.

Author contributions MN-B: Conceived and designed the work that led to the submission and acquired the data. AJ: analyzed the data. Both authors interpreted the results, drafted, and revised the manuscript and approved the final version.

\section{Compliance with ethical standards}

Conflict of interest The authors declare that they have no conflict of interest.
Open Access This article is licensed under a Creative Commons Attribution 4.0 International License, which permits use, sharing, adaptation, distribution and reproduction in any medium or format, as long as you give appropriate credit to the original author(s) and the source, provide a link to the Creative Commons license, and indicate if changes were made. The images or other third party material in this article are included in the article's Creative Commons license, unless indicated otherwise in a credit line to the material. If material is not included in the article's Creative Commons license and your intended use is not permitted by statutory regulation or exceeds the permitted use, you will need to obtain permission directly from the copyright holder. To view a copy of this license, visit http://creativecommons. org/licenses/by/4.0/.

\section{References}

1. Allen LH. How common is vitamin B-12 deficiency?. Am J Clin Nutr. 2009;89:693-696. https://doi.org/10.3945/ajen.2008.26947A

2. Hill MH, Flatley JE, Barker ME, Garner CM, Manning NJ, Olpin $\mathrm{SE}$, et al. A vitamin B-12 supplement of $500 \mu \mathrm{g} / \mathrm{d}$ for eight weeks does not normalize urinary methylmalonic acid or other biomarkers of vitamin B-12 status in elderly people with moderately poor vitamin B-12 status. J Nutr. 2013;143:142-147. https://doi. org/10.3945/jn.112.169193

3. Green R, Allen LH, Bjørke-Monsen AL, Brito A, Guéant JL, Miller JW, et al. Vitamin $\mathrm{B}_{12}$ deficiency. Nat Rev Dis Prim. 2017;3:17040. https://doi.org/10.1038/nrdp.2017.40

4. Clarke R, Birks J, Nexo E, Ueland PM, Schneede J, Scott J, et al. Low vitamin B-12 status and risk of cognitive decline in older adults. Am J Clin Nutr. 2007;86:1384-1391. https://doi.org/10. 1093/ajcn/86.5.1384

5. Porter K, Hoey L, Hughes CF, Ward M, McNulty H. Causes, consequences and public health implications of low B-vitamin status in ageing. Nutrients. 2016;8:E725. https://doi.org/10.3390/ nu8110725

6. Den Elzen WP, van der Weele GM, Gussekloo J, Westendorp RG, Assendelft WJ. Subnormal vitamin B12 concentrations and anaemia in older people: a systematic review. BMC Geriatr. 2010;10:42. https://doi.org/10.1186/1471-2318-10-42

7. Doets EL, van Wijngaarden JP, Szczecińska A, Dullemeijer C, Souverein OW, Dhonukshe-Rutten RA, et al. Vitamin B12 intake and status and cognitive function in elderly people. Epidemiol Rev. 2013;35:2-21. https://doi.org/10.1093/epirev/mxs003

8. Miles LM, Allen E, Mills K, Clarke R, Uauy R, Dangour AD. Vitamin B-12 status and neurologic function in older people: a cross-sectional analysis of baseline trial data from the Older People and Enhanced Neurological Function (OPEN) study. Am J Clin Nutr. 2016;104:790-796. https://doi.org/10.3945/ajcn.116. 137927

9. Kwok T, Lee J, Ma RC, Wong SY, Kung K, Lam A, et al. A randomized placebo controlled trial of vitamin $\mathrm{B}_{12}$ supplementation to prevent cognitive decline in older diabetic people with borderline low serum vitamin $B_{12}$. Clin Nutr. 2017;36:1509-1515. https://doi.org/10.1016/j.clnu.2016.10.018

10. He K, Merchant A, Rimm EB, Rosner BA, Stampfer MJ, Willett $\mathrm{WC}$, et al. Folate, vitamin B6, and B12 intakes in relation to risk of stroke among men. Stroke. 2004;35:169-174. https://doi.org/ 10.1161/01.STR.0000106762.55994.86

11. Larsson SC, Männistö S, Virtanen MJ, Kontto J, Albanes D, Virtamo J. Folate, vitamin B6, vitamin B12, and methionine intakes and risk of stroke subtypes in male smokers. Am J Epidemiol. 2008;167:954-961. https://doi.org/10.1093/aje/kwm395

12. Cui R, Iso H, Date C, Kikuchi S, Tamakoshi A. Japan Collaborative Cohort Study Group. Dietary folate and vitamin B6 and 
B12 intake in relation to mortality from cardiovascular diseases: Japan collaborative cohort study. Stroke. 2010;41:1285-1289. https://doi.org/10.1161/STROKEAHA.110.578906.

13. Rafnsson SB, Saravanan P, Bhopal RS, Yajnik CS. Is a low blood level of vitamin B12 a cardiovascular and diabetes risk factor? A systematic review of cohort studies. Eur J Nutr. 2011;50:97-106. https://doi.org/10.1007/s00394-010-0119-6

14. Andrès E, Loukili NH, Noel E, Kaltenbach G, Abdelgheni MB, Perrin AE, et al. Vitamin B12 (cobalamin) deficiency in elderly patients. CMAJ. 2004;171:251-259. https://doi.org/10.1503/cmaj. 1031155

15. EFSA Panel on Dietetic Products. Nutrition, and Allergies (NDA). Scientific opinion on dietary reference values for cobalamin (vitamin B12). EFSA J. 2015;13:4150. https://doi.org/10.2903/j. efsa.2015.4150

16. Roubenoff R, Baumgartner RN, Harris TB, Dallal GE, Hannan MT, Economos CD, et al. Application of bioelectrical impedance analysis to elderly populations. J Gerontol A Biol Sci Med Sci. 1997;52:M129-M136.

17. Lührmann PM, Herbert BM, Gaster C, Neuhäuser-Berthold M. Validation of a self-administered 3-day estimated dietary record for use in the elderly. Eur J Nutr. 1999;38:235-240.

18. Hartmann BM, Schmidt C, Sandfuchs K. Bundeslebensmittelschlüssel (BLS). Version 3.02. Max Rubner-Institut - Bundesforschungsinstitut für Ernährung und Lebensmittel, Karlsruhe, 2014.

19. Schwarzpaul S, Strassburg A, Lührmann PM, Neuhäuser-Berthold M. Intake of vitamin and mineral supplements in an elderly German population. Ann Nutr Metab. 2006;50:155-162. https:// doi.org/10.1159/000090728

20. Ubbink JB, Hayward Vermaak WJ, Bissbort S. Rapid highperformance liquid chromatographic assay for total homocysteine levels in human serum. J Chromatogr. 1991;565:441-446.

21. Zempleni J, Link G, Kübler W. The transport of thiamine, riboflavin and pyridoxal 5'-phosphate by human placenta. Int J Vitam Nutr Res. 1992;62:165-172.

22. Seelig HP, Wüst H. Die Kreatininbestimmung mit der Jaffé Reaktion. Ärztl Lab. 1969;15:34-39.

23. Carmel R. Biomarkers of cobalamin (vitamin B-12) status in the epidemiologic setting: a critical overview of context, applications, and performance characteristics of cobalamin, methylmalonic acid, and holotranscobalamin II. Am J Clin Nutr. 2011;94:348358. https://doi.org/10.3945/ajcn.111.013441

24. Hvas AM, Nexo E. Holotranscobalamin - a first choice assay for diagnosing early vitamin B deficiency? J Intern Med. 2005;257:289_ 298. https://doi.org/10.1111/j.1365-2796.2004.01437.x

25. Sukumar N, Adaikalakoteswari A, Venkataraman H, Maheswaran H.Saravanan P, Vitamin B12 status in women of childbearing age in the UK and its relationship with national nutrient intake guidelines: results from two National Diet and Nutrition Surveys. BMJ Open. 2016;6:e011247 https://doi.org/10.1136/bmjopen2016-011247.

26. van Wijngaarden JP, Dhonukshe-Rutten RAM, Brouwer-Brolsma EM, Enneman AW, Swart KMA, van Dijk SC, et al. Vitamin B12 intake and related biomarkers: associations in a Dutch elderly population. J Nutr Health Aging. 2017;21:1268-1276. https://doi. org/10.1007/s12603-017-0911-6

27. Bor MV, von Castel-Roberts KM, Kauwell GP, Stabler SP, Allen $\mathrm{RH}$, Maneval DR, et al. Daily intake of 4 to 7 microg dietary vitamin B-12 is associated with steady concentrations of vitamin B-12-related biomarkers in a healthy young population. Am J Clin Nutr. 2010;91:571-7. https://doi.org/10.3945/ajen.2009. 28082

28. Allen LH. Bioavailability of vitamin B12. Int J Vitam Nutr Res. 2010;80:330-5. https://doi.org/10.1024/0300-9831/a000041
29. Doets EL, In 't Veld PH, Szczecińska A, Dhonukshe-Rutten RA, Cavelaars AE, van 't Veer P, et al. Systematic review on daily vitamin B12 losses and bioavailability for deriving recommendations on vitamin B12 intake with the factorial approach. Ann Nutr Metab. 2013;62:311-22. https://doi.org/10. $1159 / 000346968$

30. Vogiatzoglou A, Smith AD, Nurk E, Berstad P, Drevon CA, Ueland PM, et al. Dietary sources of vitamin B-12 and their association with plasma vitamin B-12 concentrations in the general population: the Hordaland Homocysteine Study. Am J Clin Nutr. 2009;89:1078-1087. https://doi.org/10.3945/ajen.2008. 26598

31. Chanarin I (editor). The megaloblastic anaemias. Oxford UK: Blackwell Scientific Publications; 1969.

32. Brouwer-Brolsma EM, Dhonukshe-Rutten RA, van Wijngaarden JP, Zwaluw NL. Velde Nv, de Groot LC. Dietary sources of vitamin $\mathrm{B}-12$ and their association with vitamin B-12 status markers in healthy older adults in the B-PROOF study. Nutrients. 2015;7:7781-7797. https://doi.org/10.3390/nu7095364

33. Wahlin A, Bäckman L, Hultdin J, Adolfsson R, Nilsson LG. Reference values for serum levels of vitamin B12 and folic acid in a population-based sample of adults between 35 and 80 years of age. Public Health Nutr. 2002;5:505-511. https://doi.org/10.1079/ PHN200167

34. Refsum H, Johnston C, Guttormsen AB, Nexo E. Holotranscobalamin and total transcobalamin in human plasma: determination, determinants, and reference values in healthy adults. Clin Chem. 2006;52:129-137. https://doi.org/10.1373/ clinchem.2005.054619

35. Andrew T, Gill R, Gillham-Nasenya I, Ahmadi KR. Unravelling the basis of variability in cobalamin levels in the general population. Br J Nutr. 2013;110:1672-1679. https://doi.org/10.1017/ S0007114513000974

36. Gaskins AJ, Chiu YH, Williams PL, Ford JB, Toth TL, Hauser R, et al. Association between serum folate and vitamin B-12 and outcomes of assisted reproductive technologies. Am J Clin Nutr. 2015;102:943-950. https://doi.org/10.3945/ajcn.115.112185

37. Shane B, Stokstad EL. Vitamin B12-folate interrelationships. Annu Rev Nutr. 1985;5:115-141. https://doi.org/10.1146/a nnurev.nu.05.070185.000555

38. Owczarek D, Rodacki T, Domagała-Rodacka R, Cibor D, Mach $\mathrm{T}$. Diet and nutritional factors in inflammatory bowel diseases. World J Gastroenterol. 2016;22:895-905. https://doi.org/10. 3748/wjg.v22.i3.895

39. Lind A, Wängberg B, Ellegård L. Vitamin D and vitamin B12 deficiencies are common in patients with midgut carcinoid (SINET). Eur J Clin Nutr. 2016;70:990-994. https://doi.org/10.1038/ ejen.2016.40

40. Vlasveld LT. Low cobalamin (vitamin B12) levels in multiple myeloma: a retrospective study. Neth J Med. 2003;61:249-252.

41. Tosato M, Marzetti E, Cesari M, Savera G, Miller RR, Bernabei $\mathrm{R}$, et al. Measurement of muscle mass in sarcopenia: from imaging to biochemical markers. Aging Clin Exp Res. 2017;29:19-27. https://doi.org/10.1007/s40520-016-0717-0

42. Piyathilake CJ, Macaluso M, Hine RJ, Richards EW, Krumdieck CL. Local and systemic effects of cigarette smoking on folate and vitamin B-12. Am J Clin Nutr. 1994;60:559-566. https://doi.org/ 10.1093/ajen/60.4.559

43. Ulvik A, Ebbing M, Hustad S, Midttun Ø, Nygård O, Vollset SE, et al. Long- and short-term effects of tobacco smoking on circulating concentrations of B vitamins. Clin Chem. 2010;56:755763. https://doi.org/10.1373/clinchem.2009.137513

44. Tungtrongchitr R, Pongpaew P, Soonthornruengyot M, Viroonudomphol D, Vudhivai N, Tungtrongchitr A, et al. Relationship of tobacco smoking with serum vitamin B12, folic acid and 
haematological indices in healthy adults. Public Health Nutr. 2003;6:675-681. https://doi.org/10.1079/PHN2003483

45. Homocysteine Lowering Trialists' Collaboration. Dose-dependent effects of folic acid on blood concentrations of homocysteine: a meta-analysis of the randomized trials. Am $\mathrm{J}$ Clin Nutr. 2005;82:806-812. https://doi.org/10.1093/ajcn/82.4.806

46. Quinlivan EP, McPartlin J, McNulty H, Ward M, Strain JJ, Weir DG, et al. Importance of both folic acid and vitamin B12 in reduction of risk of vascular disease. Lancet. 2002;359:227-228. https://doi.org/10.1016/S0140-6736(02)07439-1

47. Bailey LB, Duhaney RL, Maneval DR, Kauwell GP, Quinlivan EP, Davis SR, et al. Vitamin B-12 status is inversely associated with plasma homocysteine in young women with C677T and/or A1298C methylenetetrahydrofolate reductase polymorphisms. J Nutr. 2002;132:1872-1878. https://doi.org/10.1093/jn/132.7.1872 